\title{
PENDEKATAN JELAJAH ALAM SEKITAR (JAS) PADA MATA KULIAH SISTEMATIKA HEWAN
}

\author{
Fajar Adinugraha
}

Prodi Pendidikan Biologi FKIP, Universitas Kristen Indonesia, Jakarta

Corresponding author: fadinugraha@yahoo.co.id, fajar.adinugraha@uki.ac.id

\begin{abstract}
The research objective is to describe the Jelajah Alam Sekitar (JAS) approach in Sistematika Hewan. It also to know the students ' respond of learning with the Jelajah Alam Sekitar (JAS) approach. Beside that, the research objective is to know the students' interest to the Jelajah Alam Sekitar (JAS) approach. The research is a descriptive quantitative study which uses survey and literature study method. The learning activities with the Jelajah Alam Sekitar (JAS) approach in Sistematika hewan are 1) group discussion, 2) field study, 3) practicum, 4) instructional games, 5) lecturing method, 6) project/ task giving, 7) final exam / test, and 8) practical responses. The students' response to learning by the Jelajah Alam Sekitar (JAS) approach is 89\% in good category (good and very good). Students' interest with the Jelajah Alam Sekitar (JAS) approach is $96 \%$ in interest category (interest and very interest).
\end{abstract}

Keywords: Jelajah Alam Sekiar (JAS), learning approach, students' response, students' interest

\section{PENDAHULUAN}

Mata kuliah Sistematika Hewan merupakan salah satu mata kuliah yang wajib diambil oleh mahasiswa Pendidikan Biologi di Universitas Kristen Indonesia (UKI). Mata kuliah ini ditempuh 3 sks setiap pertemuannya. Mata kuliah ini mempelajari sistem klasifikasi hewan dari phylum (tingkatan tertinggi pada kingdom hewan) hingga spesies (tingkatan terendah pada kingdom hewan). Phylum yang dipelajari mulai dari invertebrata (porifera) hingga vertebrata (chordata).

Kegiatan pembelajaran pada mata kuliah sistematika hewan ini menggunakan pendekatan Jelajah Alam Sekitar (JAS). Pendekatan Jelajah Alam Sekitar merupakan pendekatan pembelajaran yang secara komprehensif memadukan pendekatan eksplorasi dan evaluasi di mana mengandung pembelajaran yang menyenangkan (Santika, 2017). Senada dengan hal ini, Winarni (2013) dalam Samitra (2016) menyatakan bahwa Pendekatan Jelajah Alam Sekitar (JAS) merupakan pendekatan pembelajaran yang didalam kegiatannya memanfaatkan objek khususnya lingkungan sekitar secara langsung melalui kegiatan pengamatan, diskusi dan laporan hasil. Oleh karena itu, pendekatan JAS ini sesuai diterapkan pada mata kuliah Sistematika Hewan. Hal ini karena pendekatan Jelajah Alam Sekitar (JAS) memiliki prinsip-prinsip antara lain: 1) eksplorasi, 2) konstruktivsme, 3) proses sains, 4) 
learning community, 5) bioedutainment, dan 6) asesmen autentik (Alimah, 2016).

Dalam mempelajari klasifikasi hewan, mahasiswa perlu melakukan pengamatan (eksplorasi) dalam sebuah kelompok yang didukung suasana yang menyenangkan. Eksplorasi yang dimaksud bukan berarti dalam pelaksanaanya selalu melakukan pengamatan di luar kelas tetapi bisa melalui teknologi seperti internet atau sumber lain. Mata kuliah Sistematika Hewan temasuk mata kuliah yang cukup sulit. Berdasarkan penelitian Subagja (2005), mahasiswa berpendapat bahwa 1) mata kuliah taksonomi (sistematika) kurang menyenangkan atau bahkan membosankan, 2) taksonomi (sistematika) merupakan ilmu yang mandeg (kurang berkembang), 3) mahasiswa belum dapat memperoleh manfaat dari belajar taksonomi (sistematika). Selain itu, mempelajari spesies dalam klasifikasi hewan menjadi sesuatu hal yang baru bagi beberapa mahasiswa. Umumnya, mahasiswa hanya mengenal beberapa spesies saja yang ada di sekitar tempat tinggal mahasiswa.

Pendekatan Jelajah Alam Sekitar (JAS) ini sejalan dengan kurikulum sarjana berbasis KKNI di Perguruan Tinggi. Menurut Maba (2016), kurikulum berbasis KKNI mengharuskan setiap dosen tidak melaksanakan pengajaran, akan tetapi diganti dengan pembelajaran. Dengan kurikulum berbasis KKNI, pembelajaran akan menghasilkan pembentukan sikap, pengetahuan, keterampilan umum dan keterampilan khusus bagi mahasiswa. Selanjutnya, menurut Suteja (2017), kurikulum berbasis KKNI, merupakan sebuah desain kurikulum yang sangat relevan diterapkan di perguruan tinggi khususnya dalam tataran tingkat prodi dalam rangka menyiapkan SDM yang unggul dan berdaya saing di dunia kerja. Selanjutnya, agar kurikulum di perguruan tinggi dapat terlaksana dengan optimal, dibutuhkan berbagai model dan cara mengajar yang berbasis Student Centered Learning bukan lagi Teacher Centered Learning.

Berdasarkan paparan di atas, maka penulisan artikel ini bertujuan untuk 1) mendeskripsikan bentuk pendekatan Jelajah Alam Sekitar (JAS) pada mata kuliah Sistematika Hewan, 2) mengetahui penilaian mahasiswa terhadap pembelajaran dengan pendekatan Jelajah Alam Sekitar (JAS) pada mata kuliah Sistematika Hewan, dan 3) mengetahui minat mahasiswa terhadap pendekatan Jelajah Alam 
Sekitar (JAS) pada mata kuliah Sistematika Hewan.

\section{METODE PENELITIAN}

\section{Metode}

Metode penelitian dalam penelitian ini adalah deskriptif kuantitatif. Jenis penelitian ini merupakan penelitian deskriptif yang menggunakan metode studi pustaka dan survei. Menurut Siregar (2011), penelitian deskriptif adalah penelitian yang dilakukan untuk mengetahui nilai variabel mandiri, baik satu variabel atau lebih (independent) tanpa membuat perbandingan, atau penghubungan dengan variabel yang lain. Penelitian dilakukan di bulan Februari Juni 2018 pada semester genap tahun ajaran 2017/2018.

\section{Populasi dan sampel}

Populasi dalam penelitian ini adalah 63 mahasiswa program studi Pendidikan Biologi, Universitas Kristen Indonesia. Teknik pengambilan sampel dalam penelitian ini adalah non probability sampling dengan teknik sampling purposive. Sampling puposive, adalah teknik menentukan sampel dengan pertimbangan tertentu sesuai dengan tujuan yang dikehendaki.

Sampel yang digunakan adalah 31 mahasiswa rombongan belajar (rombel) mata kuliah Sistematika Hewan pada semester genap 2017/2018. Terdapat 2 (dua) rombongan belajar (rombel) yaitu rombel 1 (semester IV) dengan jumlah 20 mahasiswa dan rombel 2 (semester II) dengan jumlah 11 mahasiswa.

\section{Teknik pengumpulan dan analisis} data

1. Data deskripsi bentuk pendekatan Jelajah Alam Sekitar (JAS) pada mata kuliah Sistematika Hewan.

Pengambilan data ini melaui observasi kegiatan pembelajaran yang dilakukan dengan menggunakan pendekatan Jelajah Alam Sekitar selama satu semester. Kemudian, data tersebut dilakukan analisis dengan mendeskripsikan kegiatan pembelajaran yang dihubungkan dengan prinsipprinsip pendekatan Jelajah Alam Sekitar (JAS).

\section{Data tanggapan mahasiswa terhadap pendekatan Jelajah Alam Sekitar (JAS) pada mata kuliah Sistematika Hewan.}

Pengambilan data ini menggunakan kuesioner yang diberikan kepada mahasiswa setelah kegiatan pembelajaran berakhir di semester genap. Pengisian kuesioner dilakukan dengan mengisi melalui formulir daring dengan alamat http://gg.gg/angketsistematikahewan.

Pengisian kuesioner dilakukan pada tanggal 25 Mei hingga 20 Juni 2018. Kuesioner ini memuat 6 (enam) indikator dengan 48 butir pertanyaan 
yang disajikan pada tabel 1. Data kemudian ditabulasi dan dianalisis menggunakan kriteria sebagai berikut.

Kriteria:

$204 \leq X \leq 240=$ sangat baik

$165 \leq X \leq 203=$ baik

$126 \leq \mathrm{X} \leq 164=$ cukup

$87 \leq \mathrm{X} \leq 125=$ kurang

$48 \leq \mathrm{X} \leq 86$ = buruk

Tabel 1. Indikator pertanyaan kuesioner pendekatan JAS pada mata kuliah sistematika hewan

\begin{tabular}{llc}
\hline No & Indikator & $\begin{array}{c}\text { Jumlah } \\
\text { pertanyaan }\end{array}$ \\
\hline 1. & Eksplorasi & 6 \\
2. & Konstruktivisme & 6 \\
3. & Proses sains & 10 \\
4. & Learning & 6 \\
& community & \\
5. & Bioedutainment & 11 \\
6. & Asesmen & 9 \\
& autentik & \\
\hline
\end{tabular}

3. Data minat mahasiswa terhadap pendekatan Jelajah Alam Sekitar (JAS) pada mata kuliah Sistematika Hewan.

Pengambilan data ini juga diberikan setelah kegiatan pembelajaran sistematika hewan selesai dilakukan di akhir semester genap. Data ini bertujuan untuk melihat minat mahasiswa dalam mengikuti mata kuliah sistematika hewan selama satu semester. Kuesioner ini berisi 13 pernyataan yang pengisiannya dilakukan secara daring melalui formulir di alamat http://gg.gg/angketsistematikahewan.
Data kemudian ditabulasi dan dianalisis menggunakan kriteria sebagai berikut.

\section{Kriteria}

$$
\begin{array}{ll}
55 \leq X \leq 65 & =\text { sangat minat } \\
44 \leq X \leq 54 & =\text { minat } \\
33 \leq X \leq 43 & =\text { cukup } \\
22 \leq X \leq 32 & =\text { kurang minat } \\
13 \leq X \leq 21 & =\text { tidak minat }
\end{array}
$$

\section{HASIL DAN PEMBAHASAN}

\section{A. Deskripsi bentuk pendekatan Jelajah Alam Sekitar (JAS) pada mata kuliah Sistematika Hewan \\ Tujuan pembelajaran pada mata}

kuliah Sistematika Hewan antara lain: 1) mahasiswa memiliki keterampilan dalam pengelompokan hewan, 2) mahasiswa dapat mengembangkan ketelitian, kecermatan dan komunikasi ilmiah serta kemampuan bekerja dalam bidang taksonomi hewan, 3) mahasiswa dapat menerapkan konsep taksonomi hewan dalam penelitian taksonomi, dan 4) mahasiswa mampu mendeskripsikan karakteristik taksonomi hewan vertebrata dan invertebrata

Kegiatan pembelajaran berlangsung sebanyak 16 kali pertemuan dengan 3 sks setiap pertemuan. Kegiatan pembelajaran ini menggunakan pendekatan Jelajah Alam Sekitar (JAS). Pendekatan Jelajah Alam Sekitar (JAS) memiliki 6 (enam) prinsip yaitu 1) 
eksplorasi, 2) konstruktivisme, 3) proses sains, 4) learning community, 5) bioedutainment, dan 6) asesmen autentik. Pelaksanaan kegiatan pembelajaran Sistematika Hewan disajikan pada tabel 2 .

Diskusi kelompok dalam pembelajaran dilakukan dengan panduan lembar kerja dan materi ajar. Mahasiswa dalam kelompok kecil (3-4 anggota) melakukan diskusi sesuai materi yang ditetapkan. Waktu diskusi bervariasi antara 30-45 menit. Diskusi kelompok ini dipandu dengan materi ajar yang sudah diberikan oleh dosen di awal perkuliahan.

Tabel 2. Kegiatan pembelajaran Sistematika Hewan dengan pendekatan JAS

\begin{tabular}{|c|c|c|}
\hline No & Kegiatan pembelajaran & Prinsip Jelajah Alam Sekitar (JAS) \\
\hline 1. & Diskusi kelompok & $\begin{array}{l}\text { eksplorasi, konstruktivisme, proses sains, } \\
\text { learning community, bioedutainment, asesmen } \\
\text { autentik }\end{array}$ \\
\hline 2. & Kuliah lapangan & $\begin{array}{l}\text { eksplorasi, konstruktivisme, proses sains, } \\
\text { learning community, bioedutainment, asesmen } \\
\text { autentik }\end{array}$ \\
\hline 3. & Praktikum & $\begin{array}{l}\text { eksplorasi, konstruktivisme, proses sains, } \\
\text { learning community, asesmen autentik }\end{array}$ \\
\hline 4. & Game pembelajaran & learning community, bioedutainment, \\
\hline 5. & Metode ceramah & konstruktivisme, proses sains. \\
\hline 6. & Pemberian proyek/tugas & $\begin{array}{l}\text { eksplorasi, konstruktivisme, proses sains, } \\
\text { learning community, asesmen autentik }\end{array}$ \\
\hline 7. & Ujian Akhir Semester/ tes tertulis & asesmen autentik \\
\hline 8. & Responsi praktikum & asesmen autentik \\
\hline
\end{tabular}

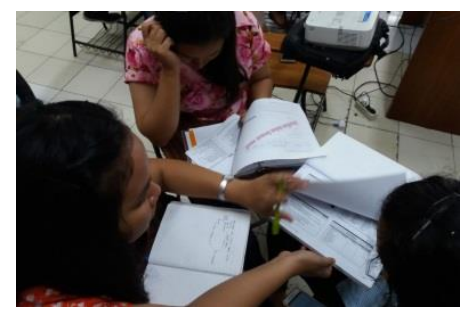

(a)

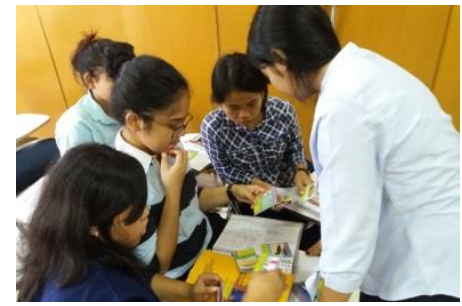

(d)

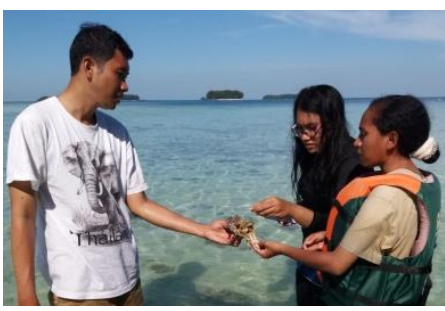

(b)

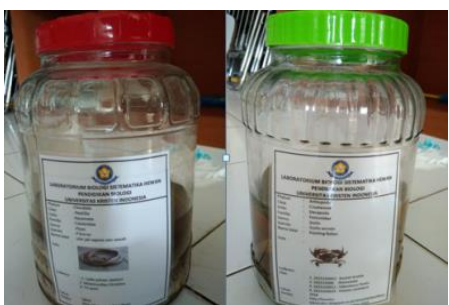

(e)

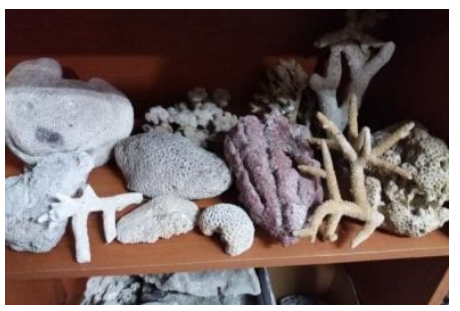

(c)

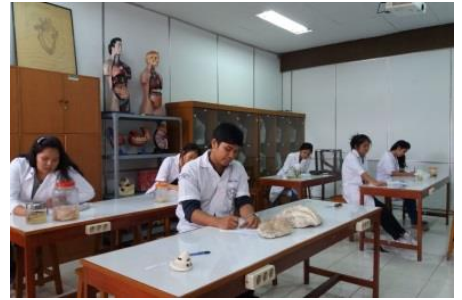

(f)

Gambar 1. Dokumentasi beberapa kegiatan pembelajaran Sistematika Hewan: (a) diskusi kelompok, (b) kuliah lapangan, (c) praktikum, (d) game, (e) pemberian proyek, (f) responsi praktikum. Sumber foto: dokumen pribadi 
Proses diskusi meliputi tahapan antara lain: pengamatan, pengumpulan data, elaborasi, dan komunikasi (gambar 1.a). Kegiatan diskusi kelompok ini selaras dengan prinsip pendekatan JAS yaitu eksplorasi, konstruktivisme, proses sains, learning community, bioedutainment, dan asesmen autentik.

Pembelajaran menggunakan metode diskusi kelompok akan memicu mahasiswa untuk mengemukakan pendapatnya sebagai tanggapan atas masalah-masalah yang ada serta merangsang kreativitas berfikir dan aktivitas (Damayanti, 2013). Selain itu, menurut penelitian Susanti (2016), metode diskusi kelompok dapat meningkatkan kemampuan berbicara secara individual dan klasikal.

Kuliah lapangan dilakukan secara integrasi dengan mata kuliah lain seperti ekologi dan taksonomi tumbuhan. Kuliah lapangan dilakukan di Pulau Harapan, Kepulauan Seribu pada bulan Maret 2018 (gambar 1.b). Kegiatan ini dilakukan dengan mengamati hewan di pantai dan di laut seperti porifera, coelenterata (koral), crustacea, penyu, dan sebagainya. Dengan mengikuti kuliah lapangan ini, pengetahuan mahasiswa mengenai hewan menjadi bertambah. Hal ini karena mahasiswa melakukan pengamatan langsung di habitatnya.

Kegiatan kuliah lapangan ini selaras dengan prinsip pendekatan JAS yaitu eksplorasi, konstruktivisme, proses sains, learning community, bioedutainment, dan asesmen autentik. Kuliah lapangan akan membuat pembelajaran menjadi lebih bermakna dan menyenangkan. Hal ini karena mahasiswa terlibat langsung dalam mengaplikasikan teori yang dipelajari di kampus dan akan terekam dalam memori mahasiswa. Selain itu, kegiatan di luar kelas akan membuat mahasiswa tidak jenuh. Menurut penelitian Ibrahim (2017), mahasiswa memberikan respon positif terhadap program kuliah lapangan karena dapat meningkatkan kebermaknaan proses pembelajaran dan efektifitas pelaksanaan kuliah lapangan.

Praktikum pada Sistematika Hewan adalah praktikum terintegrasi dengan teori (gambar 1.c). Maksudnya adalah mahasiswa melakukan praktikum setelah mempelajari teori yang sudah diberikan. Kegiatan praktikum ini memiliki kendala antara lain: kondisi ruangan laboratorium yang kurang memadai dan jumlah awetan hewan yang kurang lengkap. Namun, hal ini bisa diatasi dengan melakukan kuliah lapangan dan mencari sumber dari 
internet untuk pengamatan. Tentunya, mahasiswa melakukan pelaporan praktikum di akhir semester sebagai bentuk portofolio (asesmen).

Praktikum merupakan salah satu cara dalam merubah pembelajaran biologi yang minds on ke dalam pembelajaran yang hands on (Erwinsyah, 2016). Kegiatan praktikum selain mengandalkan otak (minds on) tetapi juga akan lebih mengaktifkan keterampilan/ psikomotorik (hands on). Kegiatan praktikum ini selaras dengan prinsip pendekatan JAS yaitu eksplorasi, konstruktivisme, proses sains, learning community, dan asesmen autentik.

Kegiatan game pembelajaran dilakukan untuk membuat suasana ruang kelas menjadi menyenangkan dan tidak jenuh. Game pembelajaran ini berupa crossword dan kartu animalia (gambar 1.d). Game pembelajaran ini termasuk dalam bioedutainment. Kegiatan game pembelajaran ini selaras dengan prinsip pendekatan JAS yaitu learning community dan bioedutainment.

Menurut Alimah (2014), pengertian strategi pembelajaran bioedutainment adalah sebagai strategi pembelajaran pengetahuan lingkungan yang menghibur dan menyenangkan. Pada strategi bioedutainment ini terkandung unsur pembelajaran ilmu, proses keilmuan, keterampilan berkarya, kerjasama, permainan yang mendidik, kompetisi, tantangan, dan sportifitas yang semuanya dikemas dalam bentuk yang menghibur sekaligus menyenangkan. Bentuk strategi bioedutainment didasarkan pada teori pembelajaran meaningful learning dan quantum learning.

Kegiatan metode ceramah tetap dilakukan dalam mata kuliah ini meskipun durasinya sekitar 30-60 menit. Menurut penulis hal ini tetap dilakukan dengan alasan bahwa sebagai bentuk penguatan terhadap teori atau konsep yang harus benar-benar dipahami mahasiswa sehingga tidak terjadi miskonsepsi. Metode ceramah bukanlah hal yang buruk tergantung bagaimana penceramah (dosen) melakukan dengan menarik dan tidak membosankan. Selain itu menurut penulis, mahasiswa perlu dilatih untuk belajar mendengarkan orang berbicara. Metode ceramah juga termasuk proses sains, meskipun tidak semua komponen proses sains terdapat dalam metode ceramah.

Menurut Pasaribu (2012), metode ceramah memiliki kelebihan antar lain: 1) suasana kelas berjalan dengan tenang, 2) tidak membutuhkan banyak tenaga dan waktu, 3) melatih pelajar (mahasiswa) untuk menggunakan 
pendengaran dengan baik, 4) lebih fleksibel dalam penggunaan waktu dan materi ajar. Kegiatan ceramah ini selaras dengan prinsip pendekatan JAS yaitu learning community dan bioedutainment.

Selanjutnya, proyek yang diberikan kepada mahasiswa adalah membuat awetan basah dari hewan yang sudah ditentukan (gambar 1.e). Selain sebagai tugas, hal ini dilakukan sebagai bentuk solusi terhadap ketersediaan awetan yang kurang lengkap di laboratorium sehinggak kegiatan praktikum dapat berjalan dengan baik. Kegiatan pemberian proyek/tugas ini selaras dengan prinsip pendekatan JAS yaitu eksplorasi, konstruktivisme, proses sains, learning community, asesmen autentik. Menurut penelitian Adinugraha (2012) mengatakan bahwa model pembelajaran berbasis proyek memberikan pengaruh terhadap sikap ilmiah. Selain itu, di dalam pemberian proyek akan muncul keterampilan proses sains dalam diri mahasiswa.

Kegiatan ujian atau tes tertulis. Kegiatan ini masih dilakukan sebagai bentuk untuk mengukur kemampuan kognitif mahasiswa. Hal ini penting dilakukan mengingat mahasiswa yang mengambil mata kuliah ini dipersiapkan untuk menjadi seorang guru. Sungguh disayangkan apabila calon guru tidak memiliki kemampuan kognitif yang baik.

Selain itu, ujian atau tes tertulis ini mengajarkan kepada mahasiswa untuk berperilaku jujur dan percaya diri pada kemampuan diri sendiri. Menurut Afifah (2017), mengatakan bahwa Ujian Akhir Semester dapat digunakan sebagai uji kemampuan, pengetahuan, dan kejujuran. Meskipun demikian, penilaian hasil belajar pada mata kuliah ini bukan hanya dari nilai tes tertulis saja. Kegiatan ujian tertulis ini selaras dengan prinsip pendekatan JAS yaitu asesmen autentik.

Kegiatan responsi praktikum pada mata kuliah ini merupakan kegiatan tanya jawab setelah semua praktikum dilaksanakan (gambar 1.f). Mahasiswa bergiliran menjawab pertanyaan seputar sistematika hewan yang terdapat di meja, di mana di meja tersebut terdapat awetan hewan basah dan taksidermi (awetan hewan yang dikeringkan). Hal ini bertujuan sebagai alat evaluasi terhadap kemampuan praktikum mahasiswa. Kegiatan responsi praktikum ini selaras dengan prinsip pendekatan JAS yaitu asesmen autentik.

\section{B. Tanggapan mahasiswa terhadap pendekatan Jelajah Alam Sekitar (JAS) pada mata kuliah Sistematika Hewan}

Setelah perkuliahan berjalan selama 16 pertemuan, mahasiswa 
mengisi kuesioner secara daring. Pengisian kuesioner ini bertujuan untuk mengetahui gambaran pelaksanaan kegiatan pembelajaran Sistematika Hewan dengan menggunakan pendekatan Jelajah Alam Sekitar (JAS). Hal ini dirasa perlu karena dapat digunakan sebagai penilaian terhadap kegiatan pembelajaran apakah sesuai dengan prinsip Jelajah Alam Sekitar atau tidak. Selain itu, juga sebagai evaluasi untuk perbaikan pembelajaran di semester berikutnya.

Berdasarkan data, dari 31 responden hanya 27 responden yang menjawab lewat formulir daring. Menurut penulis, formulir daring memang memiliki kelemahan yaitu tidak semua responden akan mengisi dengan tepat waktu. Namun, data yang terkumpul sekitar $87 \%$ sehingga mencukupi untuk digunakan sebagai gambaran. Pertanyaan kuesioner ini memiliki skala $1-5$ dengan kriteria sangat baik, baik, cukup, kurang, dan buruk. Data mengenai tanggapan mahasiswa terhadap pembelajaran Sistematika Hewan per indikator dapat dilihat pada tabel 2 dan gambar 2 .

Kegiatan eksplorasi dan proses sains mendapatkan penilaian kategori cukup oleh mahasiswa. Kegiatan eksplorasi dan proses sains berkaitan dengan praktikum. Hal ini karena laboratorium yang dimiliki hanya satu ruangan. Selain itu, ukuran laboratorium kurang memadai dan jadwal penggunaan bertabrakan dengan mata kuliah lain. Namun, masalah ini sudah diatasi dengan adanya laboratorium baru dan akan terus diupayakan untuk menambah jumlah laboratorium dan awetan. Hal ini dimaksudkan agar mahasiswa dapat melakukan kegiatan eksplorasi dengan maksimal sehingga proses sains bisa berjalan dengan baik. Kekurangan ini juga diatasi dengan melakukan kegiatan kuliah lapangan sehinga mahasiswa dapat melakukan praktikum di habitat hewan dan langsung melihat interaksinya.

Tabel 2. Tanggapan mahasiswa terhadap pembelajaran Sistematika Hewan dengan pendekatan JAS per indikator

\begin{tabular}{llc}
\hline No & Indikator & $\begin{array}{l}\text { Rata-rata } \\
\text { skor }\end{array}$ \\
\hline 1. & Eksplorasi & 3,33 \\
2. & Konstruktivisme & 4,11 \\
3. & Proses sains & 3,67 \\
4. & Learning community & 4,08 \\
5. & Bioedutainment & 4,12 \\
6. & Asesmen autentik & 4,13 \\
\hline
\end{tabular}

Penilaian mahasiswa terhadap indikator konstruktivisme, learning community, bioedutainment, dan asesmen autentik berada pada kriteria baik yaitu dengan rata-rata 4. Data disajikan pada tabel 2 dan gambar 2 . 


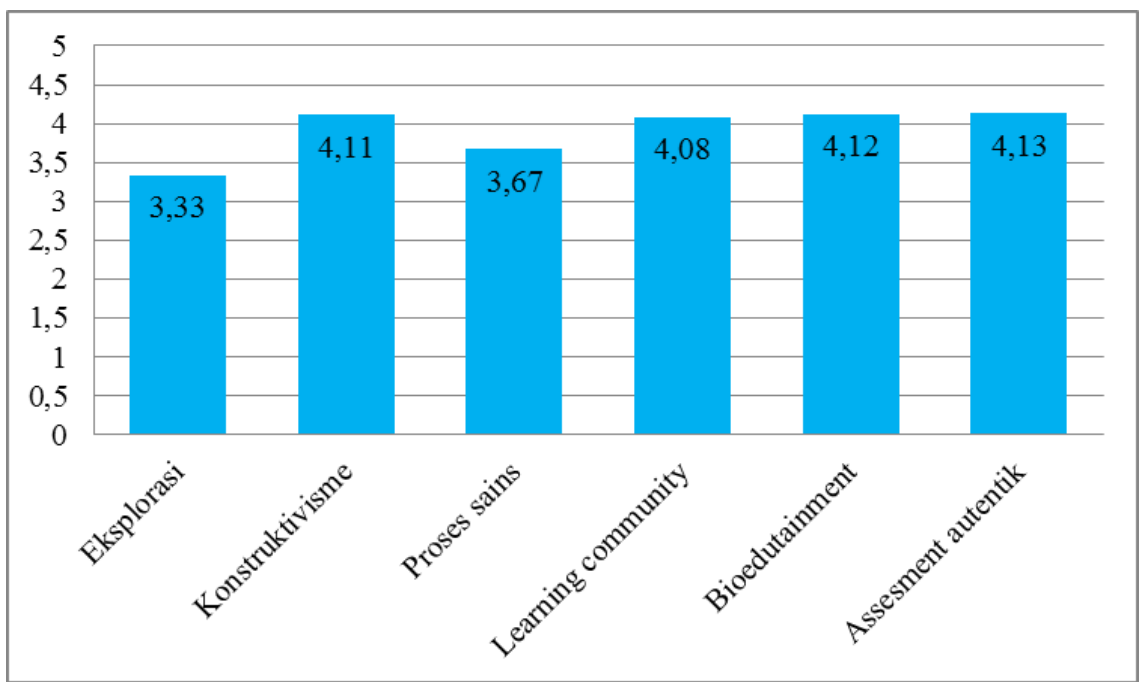

Gambar 2. Grafik tanggapan mahasiswa terhadap pembelajaran Sistematika Hewan dengan pendekatan JAS per indikator.

Berdasarkan data secara keseluruhan, responden (mahasiswa) memberikan tanggapan yang baik terhadap pelaksanaan pembelajaran dengan presentase sebesar $89 \%$ (baik $63 \%$ dan sangat baik 26\%). Sekitar $11 \%$ responden mengatakan bahwa pelaksanaan pembelajaran dengan pendekatan JAS adalah cukup baik. Data tanggapan mahasiswa terhadap pembelajaran Sistematika Hewan dapat dilihat pada tabel 3 .

Tabel 3. Tanggapan mahasiswa terhadap pembelajaran Sistematika Hewan dengan pendekatan JAS

\begin{tabular}{llc}
\hline No & Indikator & $\begin{array}{l}\text { Jumlah } \\
\text { responden }\end{array}$ \\
\hline 1. & Sangat baik & 7 \\
2. & Baik & 17 \\
3. & Cukup & 3 \\
\hline
\end{tabular}

Selain enam indikator di atas, hal yang menjadi ciri khas pendekatan JAS antara lain: 1) selalu dikaitkan dengan alam sekitar secara langsung maupun tidak langsung yaitu dengan menggunakan media; 2) selalu ada kegiatan berupa peramalan (prediksi), pengamatan, dan penjelasan; 3) terdapat laporan untuk dikomunikasikan baik secara lisan, tulisan, gambar, foto atau audiovisual; dan 4) dirancang menyenangkan sehingga akan menimbulkan minat untuk belajar lebih lanjut (Alvitasari, 2016).

Hasil penelitian ini juga dijadikan sebagai evaluasi kegiatan pembelajaran. Hal ini karena pelaksanaan pada mata kuliah sistematika hewan masih terdapat kekurangan yang akan terus diperbaiki untuk tahun berikutnya. Diagram tanggapan mahasiswa terhadap pembelajaran Sistematika Hewan dengan pendekatan JAS disajikan pada gambar 3. 


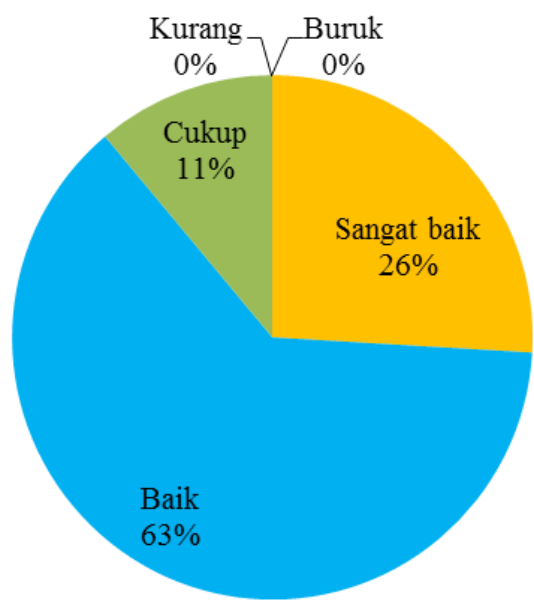

(a)

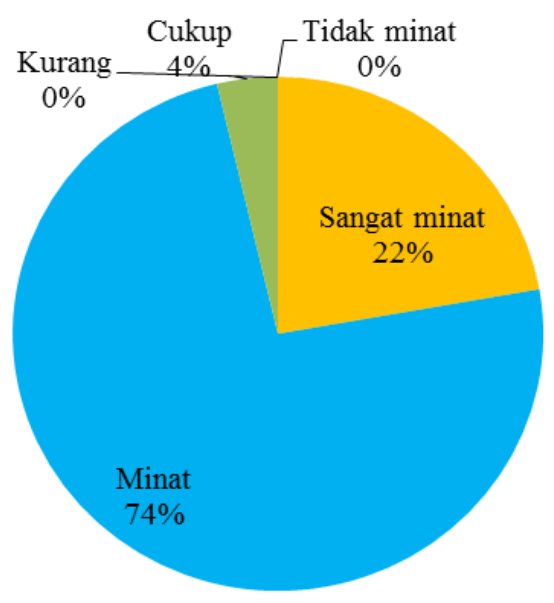

(b)

Gambar 3. Diagram tanggapan mahasiswa terhadap pembelajaran Sistematika Hewan dengan pendekatan JAS secara umum (a), dan diagram minat mahasiswa mahasiswa terhadap pembelajaran Sistematika Hewan dengan pendekatan JAS (b).

C. Minat mahasiswa terhadap mata kuliah Sistematika Hewan dengan pendekatan Jelajah Alam Sekitar (JAS).

Minat belajar mahasiswa merupakan salah satu faktor yang mempengaruhi proses pembelajaran. Apabila mahasiswa sudah tidak memiliki minat untuk mengikuti pembelajaran, maka akan berakibat pada aktivitas belajar dan hasil belajar. Oleh karena itu, diharapkan dengan menggunakan pendekatan Jelajah Alam Sekitar (JAS), mahasiswa memiliki minat yang tinggi dalam mengikuti pembelajaran Sistematika Hewan.

Responden mengisi kuesioner yang berisi 13 pertanyaan dengan skala 1 sampai 5. Kemudian, data dikategorikan dari kategori tidak minat hingga sangat minat. Berdasarkan data, mahasiswa yang memiliki minat terhadap mata kuliah Sistematika Hewan adalah sebesar $96 \%$ (yaitu terdiri dari $22 \%$ sangat minat dan $74 \%$ minat). Terdapat sekitar 4\% mahasiswa mengatakan cukup minat terhadap mata kuliah Sistematika Hewan. Rekapitulasi data minat mahasiswa disajikan pada tabel 4 .

Tabel 3. Tanggapan mahasiswa terhadap pembelajaran Sistematika Hewan dengan pendekatan JAS

\begin{tabular}{llc}
\hline No & Indikator & $\begin{array}{l}\text { Jumlah } \\
\text { responden }\end{array}$ \\
\hline 1. & Sangat minat & 6 \\
2. & Minat & 20 \\
3. & Cukup & 1 \\
\hline
\end{tabular}

Menurut Djaali (2007) dalam Jirana (2015), minat seseorang terhadap suatu obyek akan membawa suatu kecenderungan untuk bergaul lebih dekat dengan obyek yang diminatinya. Kenyataan ini berlaku dalam belajar ketika mahasiswa memiliki minat yang besar terhadap mata kuliah 
biologi, maka secara otomatis mahasiswa dapat berperan aktif dalam pembelajaran biologi, baik secara tindakan maupun secara mental.

Minat belajar juga dipengaruhi oleh beberapa faktor. Menurut penelitian Fitriya (2013), sekitar 37,5\% minat belajar mahasiswa dipengaruhi oleh intensitas perhatian orang tua dan ketersediaan sumber belajar, sisanya sebesar $62,5 \%$ dipengaruhi oleh faktor lain.

\section{KESIMPULAN}

Berdasarkan pembahasan di atas, maka simpulan dalam artikel ini adalah sebagai berikut.

1. Kegiatan pembelajaran dengan pendekatan Jelajah Alam Sekitar (JAS) pada mata kuliah Sistematika Hewan meliputi: 1) diskusi kelompok, 2) kuliah lapangan, 3) praktikum, 4) game pembelajaran, 5) metode ceramah, 6) pemberian proyek/tugas, 7) ujian akhir semester/ tes tertulis, dan 8) responsi praktikum.

2. Tanggapan mahasiswa terhadap pembelajaran dengan pendekatan Jelajah Alam Sekitar (JAS) pada mata kuliah Sistematika Hewan, berada pada kategori baik yaitu $89 \%$ (baik dan sangat baik).

3. Minat mahasiswa terhadap pembelajaran dengan pendekatan Jelajah Alam Sekitar (JAS) pada mata kuliah Sistematika Hewan, berada pada kategori minat yaitu 96\% (sangat minat dan minat).

\section{DAFTAR PUSTAKA}

Adinugraha F. 2017. Pengaruh model pembelajaran dan efikasi diri terhadap sikap ilmiah siswa sma peminatan mipa. Jurnal Pro-Life, 4 (3) : 441-455.

Afifah N. 2017. UAS: Uji kemampuan, pengetahuan, dan kejujuran. Artikel online. On line at http://news.unair.ac.id [diakses 28 Juni 2018].

Alimah S \& Aditya Marianti. 2016. Jelajah alam sekitar: pendekatan, strategi, model, dan metode pembelajaran biologi berkarakter untuk konservasi. Semarang: UNNES.

Alvitasari D. 2016. Pendekatan jelajah alam sekitar denan memanfaatkan laboratorium biologi dan kebun wisata pendidikan unnes sebagai sumbr belajar materi keanekaragaman hayati. Skripsi. On line at http://lib.unnes.ac.id [diakses 28 Juni 2018].

Damayanti FL. 2013. Penerapan model diskusi kelompok dengan menggunakan media handout untuk meningkatkan aktivitas dan kreativitas. Jurnal Studi Sosial. On 
line at https://media.neliti.com [diakses 28 Juni 2018].

Erwinsyah R, Riandi Riandi, dan Mimin Nurjhani. 2016. Relevansi praktikum dan perkuliahan teori pada mata kuliah genetika. Proceeding Biology Education Conference, 13 (1): 546-553.

Fitriya SM. 2013. Minat belajar mahasiswa ditinjau dari intensitas perhatian orang tua dan ketersediaan sumber belajar pada mahasiswa fkip universitas muhammadiyah surakarta. Naskah publikasi FKIP-Universitas Muhammadiyah Surakarta. 1-10.

Ibrahim Y, Riandi Riandi, dan Hertien Koebandiah Surtikanti. 2017. Persepsi mahasiswa terhadap pengembangan program kuliah lapangan terpadu (integrated field trip). Jurnal Biosfer Jurnal Bio dan Pendidikan Bio, 1 (1): 43-47.

Jirana J, Syamsiara Nur, dan Nurmiati Nurmiati. 2015. Faktor-faktor yang mempengaruhi kesulitan dan minat belajar mahasiswa jurusan pendidikan biologi universitas sulawesi barat. Jurnal Saintifik, 1 (2): 87-94.

Maba W. 2016. Kuriklum sarjana berbasis kkni mengubah mintset pengajaran menjadi pembelajaran. Jurnal Bakti Saraswati, 5 (1): 8587.

Pasaribu LM. 2012. Pengaruh metode ceramah dengan menggunakan media realita terhadap peningkatan hasil belajar siswa pada mata pelajarn ipa kelas $\mathrm{v}$ semester ii sdn kutowinangun 07 tahun pelajaran 2011/2012. Skripsi. Online at http://repository.uksw.edu [diakses 28 Juni 2018].

Samitra D, Mareta Widiya, Nurwita Dwi Rahmasari. 2016. Pengaruh Pendekatan Jelajah Alam Sekitar (JAS) terhadap keterampilan proses dan hasil belajar biologi siswa kelas $X$ sma negeri 5 lubuklinggau. Jurnal Bioedukatika, 4 (2): 8-13.

Santika AM, Desak Nyoman Budiningsih, Cornelius Sri Murdo Yuwono. 2017. Pendekatan jelajah alam sekita (jas) berbasis pelestarian jalak bali terhadap kepedulian lingkungan dan hasil peta kognitif siswa. Jurnal Santiaji Pendidikan, 7 (1): 55-66.

Siregar S. 2011. Statistika deskriptif untuk penelitian. Jakarta: Rajawali Press.

Subagja J. 2005. Pembelajaran taksonomi fauna di perguruan tinggi. Jurnal Zoo Indonesia, 15 (2): 101-105.

Susanti S. 2016. Penerapan metode diskusi dalam meningkatkan kemampuan berbicara siswa kelas iv sdn ogogili. Jurnal Kreatif Tadulako, 4(8): 159-172.

Suteja J. 2017. Model-model pembelajaran dalam kurikulum berbasis kompetensi kkni di perguruan tinggi (perubahan dari teacher centered learning ke arah student centered learning). Jurnal Edueksos, 6 (1): 81-100. 